\title{
Analisis faktor konsentrat pakan terhadap konsumsi asam-asam amino ayam ras petelur
}

\author{
W. Utiah* dan U. Paputungan \\ Fakultas Peternakan Universitas Sam Ratulangi Manado, 95115 \\ *Korespondensi (corresponding author): wapsiatyutiah@yahoo.co.id
}

\begin{abstract}
ABSTRAK
Ayam petelur memerlukan sejumlah unsur-unsur nutrisi seperti protein yang di dalamnya terkandung asam-asam amino yang seimbang dan berkualitas. Sekarang ini banyak tersedia berbagai jenis ransum komersial (konsentrat) untuk ayam petelur yang diproduksi oleh perusahaan makanan ternak. Kualitas protein dalam konsentrat dinyatakan tinggi atau rendah tergantung dari asam-asam amino esensial yang terkandung dalam bahan makanan tersebut. Tujuan penelitian ini untuk mengetahui apakah ada pengaruh pemberian jenis konsentrat komersial yang berbeda terhadap konsumsi asam-asam amino ayam ras petelur. Penelitian ini dilaksanakan pada peternakan ayam ras petelur yeng terletak di Kelurahan Matali Kecamatan Kotamobagu Timur Kota Kotamobagu. Ayam petelur yang digunakan adalah Strain Silver sebanyak 240 ekor berumur 78 minggu. Penelitian ini menggunakan Rancangan acak Lengkap (RAL) yang terdiri dari 3 perlakuan dan 8 ulangan. Rancangan ini digunakan untuk menganalisis pengaruh perlakuan tiga jenis konsentrat komersil terhadap konsumsi asam-asam amino yaitu Konsentrat komersil A (RA), Konsentrat komersil B (RB) dan Konsentrat komersil C (RC). Hasil penelitian menunjukkan bahwa sebagian besar (80 \%) jumlah asamasam amino esensial (Arginine, Lysine, Histidine, Leucine, Isoleucine, Valine, Threonine dan Phenylalanine) lebih tinggi pada RC dibanding RB dan RA, itu berarti komposisi asam-asam amino baik itu kualitas dan kuantitas dalam konsentrat komersil C (RC) adalah cukup dan lebih seimbang dibanding konsentrat komersil A (RA) dan konsentrat komersil B (RB). Asam-asam amino yang lengkap dalam RC meningkatkan jumlah konsumsi pakan oleh ayam petelur dibandingkan konsumsi pada RA dan RB.
\end{abstract}

Kata kunci : Ayam ras petelur, asam-asam amino, konsentrat komersil

\begin{abstract}
ANALYSIS OF FEED CONCENTRATE FACTOR ON LAYING HEN AMINO ACIDS CONSUMPTION. Laying hens require a number of elements in which nutrients such as protein containing the amino acids are balanced in quality. Recently, there are various types of commercial ration (concentrate) for laying hens produced by the company. Quality of protein is expressed either high or low composition of amino acids depending on the essential amino acids contained in these feeds. The purpose of this study was to determine the effect of different types of commercial concentrates on the consumption of amino acids in laying chicken. The research was conducted on laying chicken farms located in Matali Village, district of East Kotamobagu, Kotamobagu Municipality. Laying hens of Silver Strains as many as 240 heads at 78-week-old were used in this study. This study applied a completely randomized design (CRD) consisting of three treatments and eight replications at each treatment. The treatments were using commercial concentrations of the amino acids for commercial Concentrate A (RA), commercial concentrate B (RB) and commercial concentrate $\mathrm{C}(\mathrm{RC})$. The laboratory analysis
\end{abstract}


showed that the majority amounts of essential amino acids (Arginine, Lysine, histidine, leucine, isoleucine, valine, threonine and phenylalanine) of $80 \%$ was higher in RC than RB and RA, indicating that the composition of both quality and quantity of amino acids in commercial concentrates $\mathrm{C}(\mathrm{RC})$ is sufficient and more balanced than commercial concentrates A (RA) and commercial concentrate B (RB). These complete amino acids in RC increased more feed consumption of laying hens compared with those in RA and RB.

Key words: Laying hens, amino acids, commercial concentrate

\section{PENDAHULUAN}

Ayam ras petelur dapat berproduksi dengan baik apabila segala yang dibutuhkan oleh ayam tersebut terpenuhi. Kelebihan dari yang dibutuhkan barulah digunakan untuk produksi. Untuk keperluan hidupnya dan untuk produksi ayam membutuhkan sejumlah unsur-unsur nutrisi yaitu protein (asam-asam amino yang seimbang dan berkualitas), energy yang berintikan karbohidrat dan lemak, vitamin dan mineral. Semua unsur nutrisi itu diambil dari luar tubuh ayam, unsurunsur nutrisi yang diambil dari luar itu dibutuhkan ayam dalam jumlah tertentu tidak lebih dan tidak kurang (Hegazy dan Badawy, 2010).

Dalam membahas kebutuhan protein bahwa pada hakekatnya kita membahas kebutuhan akan asam amino (Suprijatna et al, 2005; Amrullah, 2004; Banerjee, 1982). Protein ransum haruslah yang seimbang dan berkualitas sehingga ayam petelur dapat berproduksi maksimum dan tetap ekonomis (Hardjosubroto dan
Astuti, 1993; Bunglavan et al., 2014: Cai et al., 2012; Delezie et al., 2014). Dari sekian banyak asam amino methionine seringkali defisien oleh karena itu asam amino ini harus dapat dipastikan kecukupannya (Jacob et al., 2000; Kazemi et al., 2013; Jing et al., 2015). Konsumai asam amino esensial yang dianjurkan bagi ayam petelur pada berbagai fase produksi dapat dilihat pada Tabel 1.

Konsentrat adalah campuran bahan pakan ternak yang tinggi mutu gizinya dan mudah dicerna. Ransum ini biasanya mengandung kadar protein yang tinggi dan serat kasar rendah (Hardjosubroto dan Astuti, 1993). Nesheim et al. (1979) menyatakan konsentrat adalah campuran dari bahan-bahan makanan yang membentuk suatu bahan makanan yang komplit serta zat-zat makanan yang seimbang. Konsentrat merupakan bahan makanan ternak berprotein tinggi yang disusun sedemikian rupa dan bahan-bahan pakan seperti tepung ikan, bungkil kelapa, bungkil kedelai, tepung daging dan tulang, pollard, bungkil kacang tanah, canola,

Tabel 1. Konsumsi Asam Amino Yang Dianjurkan Bagi Petelur Pada Berbagai Fase Produksi

\begin{tabular}{lccc}
\hline Asam Amino (mg/hari) & $\begin{array}{c}\text { Fase I } \\
(1-2 \text { Minggu })\end{array}$ & $\begin{array}{c}\text { Fase II } \\
(21-40 \text { Minggu })\end{array}$ & $\begin{array}{c}\text { Fase III } \\
\text { (> 41 Minggu })\end{array}$ \\
\hline Arginin & 950 & 875 & 825 \\
Lisine & 800 & 750 & 725 \\
Methionine & 385 & 360 & 350 \\
Methionine + Sistine & 700 & 650 & 625 \\
Triptophan & 190 & 175 & 170 \\
\hline
\end{tabular}

Sumber : Amrullah (2004). 
pollard, bungkil kacang tanah, canola, vitamin, kalsium, fosfat dan trace mineral. Sekarang ini banyak tersedia berbagai jenis ransum komersial (konsentrat) untuk ayam petelur yang diproduksi oleh perusahaan makanan ternak, dimana komposisi zat-zat makanannya telah tercantum sehingga nilai nutrisi pakan yang disusun dapat dihitung kadarnya (Nassiri-Moghaddam et al., 2012; Mohapatra et al., 2014; Markovic et al., 2018). Atas dasar pemikiran di atas telah dilakukan penelitian dengan tujuan untuk mengetahui apakah ada pengaruh pemberian jenis konsentrat komersil merek berbeda terhadap konsumsi asam-asam amino ayam ras petelur.

\section{MATERI DAN METODE PENELITIAN}

Ternak yang digunakan dalam penelitian ini adalah ayam ras petelur starin silver umur 78-86 minggu yang dibeli/berasal dari PT. Charoen Phokphan berjumlah 240 ekor. Kandang yang digunakan adalah sisitim baterai yang terbuat dari bambu dengan ukuran $40 \mathrm{~cm} \mathrm{x}$ $25 \mathrm{~cm}$ x $40 \mathrm{~cm}$ terdiri dari 240 unit kandang yang masing-masing dilengkapi tempat makan dan minum, untuk menimbang pakan ternak yang dikonsumsi tiap hari digunakan timbangan dengan kapasitas 500 $\mathrm{kg}$ dan timbangan digital merek Tanika

Tabel 2. Kandungan Zat-zat Makanan Dalam Bahan Pakan Penyusun Ransum Penelitian

\begin{tabular}{lccccc}
\hline \multirow{2}{*}{$\begin{array}{l}\text { Kandungan } \\
\text { Zat-zat } \\
\text { Makanan }\end{array}$} & $\begin{array}{c}\text { Jagung } \\
\text { Kuning }\end{array}$ & $\begin{array}{c}\text { Dedak } \\
\text { Halus }\end{array}$ & $\begin{array}{c}\text { Konsentrat } \\
\text { Komersil A } \\
(\mathrm{RA})^{+}\end{array}$ & $\begin{array}{c}\text { Konsentrat } \\
\text { Komersil B } \\
(\mathrm{RB})^{+}\end{array}$ & $\begin{array}{c}\text { Kpnsentrat } \\
\text { Kpmersil C } \\
(\mathrm{RC})^{+}\end{array}$ \\
\cline { 2 - 6 } Protein (\%) & 8,90 & 13,80 & 37,00 & 32,00 & 36,00 \\
Lemak (\%) & 3,90 & 14,10 & 3,50 & 3,50 & 3,00 \\
Serat Kasar (\%) & 2,20 & 11,20 & 8,00 & 8,00 & 10,00 \\
Kalsium (\%) & 0,02 & 0,07 & 12,00 & 3,50 & 11,00 \\
Phospor (\%) & 0,30 & 1,66 & 1,80 & 1,50 & 1,00 \\
Energi Met & 3325 & 2200 & 2620 & 2444 & 3391 \\
(kkal/kg) & & & & & \\
\hline Asam-Asam & Jagung & Dedak & Konsentrat & Konsentrat & Konsentra \\
Amino & Kuning & Halus & Komersil A & Komersil B & Komersil C \\
& & & $(\mathrm{RA})^{++}$ & $(\mathrm{RB})^{++}$ & $(\text {RC) })^{++}$ \\
\hline Arginin (\%) & 0,43 & 0,65 & 2,39 & 2,19 & 2,67 \\
Lysine (\%) & 0,27 & 0,31 & 1,79 & 1,65 & 1,99 \\
Leucine (\%) & 1,06 & 0,62 & 2,55 & 2,69 & 3,48 \\
Isoleucine (\%) & 0,32 & 0,36 & 1,55 & 1,46 & 1,83 \\
Valine (\%) & 0,40 & 0,50 & 1,66 & 1,67 & 2,13 \\
Methionine (\%) & 0,18 & 0,18 & 0,72 & 0,80 & 0,58 \\
Threonine (\%) & 0,32 & 0,28 & 1,00 & 0,93 & 1,50 \\
Glycine (\%) & 0,32 & 0,81 & 2,17 & 1,98 & 2,02 \\
Phenylalanine & 0,42 & 0,38 & 1,58 & 1,54 & 2,07 \\
(\%) & & & & & \\
\hline Sumber : & & & & \\
\hline
\end{tabular}

Sumber :

*) NRC (1984)

**) Banerjee (1982)

+) Hasil Analisis Produsen Masing-masing Konsentrat Komersil (Brosur)

++) Hasil Analisis Laboratorium Terpadu IPB Bogor (2007) 
Tabel 3. Komposisi Bahan Pakan, Zat-zat Makanan dan Asam Amino Ransum Penelitian

\begin{tabular}{lccc}
\hline \multirow{2}{*}{ Bahan Pakan } & \multicolumn{3}{c}{ Komposisi Dalam Ransum } \\
\cline { 2 - 4 } & RA & RB & RC \\
\hline Jagung Kuning (\%) & 55 & 55 & 55 \\
Dedak Halus (\%) & 18 & 18 & 18 \\
Konsentrat Komersil A (\%) & 27 & - & - \\
Konsentrat Komersil B (\%) & - & 27 & - \\
Konsentrat Komersil C (\%) & - & - & 27 \\
\hline
\end{tabular}

Zat-zat Makanan Hasil Perhitungan dari Tabel 2

\begin{tabular}{lccc}
\hline Protein $(\%)$ & 17,36 & 16,01 & 17,09 \\
Lemak (\%) & 5,62 & 5,62 & 5,49 \\
Serat Kasar (\%) & 5,38 & 5,38 & 5,92 \\
Kalsium (\%) & 3,26 & 0,97 & 3,09 \\
Phospor (\%) & 0,94 & 0,87 & 0,73 \\
Energi Metabolis (kkal/kg) & 2932 & 2884 & 3140 \\
\hline
\end{tabular}

Zat-zat Makanan Hasil Analisis Laboratorium*

\begin{tabular}{|c|c|c|c|}
\hline Protein $(\%)^{+}$ & 15,33 & 13,62 & 14,42 \\
\hline Lemak $(\%)^{+}$ & 5,13 & 5,16 & 4,56 \\
\hline Serat Kasar $(\%)^{+}$ & 5,53 & 4,78 & 5,24 \\
\hline Kalsium $(\%)^{++}$ & 4,25 & 1,12 & 3,15 \\
\hline Phospor $(\%)^{++}$ & 0,091 & 0,087 & 0,081 \\
\hline Energi Metabolis $(\mathrm{kkal} / \mathrm{kg})^{+}$ & 29950,5 & 2972,4 & 2765,6 \\
\hline \multicolumn{4}{|c|}{ Asam-asam Amino Hasil Perhitungan Dari Tabel 2.} \\
\hline $\operatorname{Arginin}(\mathrm{g} / \mathrm{kg})$ & 9,990 & 9,448 & 10,744 \\
\hline Lysine $(\mathrm{g} / \mathrm{kg})$ & 6,876 & 6,498 & 7,416 \\
\hline Histidine $(\mathrm{g} / \mathrm{kg})$ & 3,887 & 3,725 & 4.562 \\
\hline Leucine $(\mathrm{g} / \mathrm{kg})$ & 13,831 & 14,209 & 16,342 \\
\hline Isoleucine $(\mathrm{g} / \mathrm{kg})$ & 6,593 & 6,350 & 7,345 \\
\hline Valin $(\mathrm{g} / \mathrm{kg})$ & 7,083 & 7,609 & 8,851 \\
\hline Methionine $(\mathrm{g} / \mathrm{kg})$ & 3,258 & 3,474 & 2,880 \\
\hline Threonine (g/kg) & 4,964 & 4,775 & 6,314 \\
\hline Glycine $(\mathrm{g} / \mathrm{kg})$ & 9,077 & 8,564 & 8,672 \\
\hline Phenylalanine $(\mathrm{g} / \mathrm{kg})$ & 7,260 & 7,152 & 8,583 \\
\hline
\end{tabular}

Keterangan :

+) Hasil analisis Laboratorium Balai Riset dan Standarisasi Industri, Manado (2007)

++ Hasil analisis Laboratorium Fakultas Peternakan Universitas Sam Ratulangi Manado (2007).

*) Digunakan dalam perhitungan konsumsi asam-asam amino ayam petelur

kapasitas 3000 gram.

Bahan-bahan yang digunakan sebagai penyusun ransum dalam penelitian ini yaitu jagung kuning, dedak halus, konsentral komersil A, Konsentrat komersil
B, Konsentrat Komersil C. Adapun Kandungan zat-zat makanan dalam bahan pakan penyusun ransum penelitian dapat dilihat pada Tabel 2. Selanjutnya komposisi bahan pakan, zat-zat makanan dan asam 
amino ransum penelitian dapat dilihat pada Tabel 3. Penelitian ini menggunakan Rancangan Acak Lengkap (RAL) yang terdiri dari 3 perlakuan dan 8 ulangan (Steel and Torrie, 1993). Dalam setiap ulangan terdapat 10 ekor ayam ras petelur. Dalam penelitian ini, perlakuan dalam percobaan adalah :

RA: Jagung kuning (55\%) + Dedak halus $(18 \%)+$ Konsentrat komersil A (27\%).

RB: Jagung kuning (55\%) + Dedak halus $(18 \%)+$ Konsentrat komersil B $(27 \%)$. RC: Jagung kuning (55\%) + Dedak Halus $(18 \%)+$ Konsentrat komersil C (27\%).

Data hasil penelitian ini dianalisis dengan analisis varians dan untuk mengetahui perlakuan-perlakuan mana yang berbeda nyata secara statistik dilakukan pengujian dengan Uji Beda Nyata Jujur (BNJ). Ransum yang akan diberikan pada ternak percobaan yaitu RA, $\mathrm{RB}$ dan RC masing-masing diadakan diadakan pencampuran terlebih dahulu sesuai dengan perlakuan, kemudian ditimbang untuk konsumsi ransum selama tiga hari. Jumlah yang diberikan pada ternak percobaan untuk setiap perlakuan yaitu 120 gram x 3 hari x 80 ekor $=28800$ gram berarti pemberian ransum selama tiga hari disediakan sebanyak $\pm 30 \mathrm{~kg}$ ransum setiap perlakuan. Pemberian makanan pada ternak percobaan dilakukan 3 kali sehari yaitu pada jam $06.00-07.00 ; 12.00-$ $13.00 ; 16.00-17.00$.

\section{HASIL DAN PEMBAHASAN}

Rataan jumlah konsumsi asam-asam amino dari ayam-ayam petelur Strain Silver umur 78 - 86 minggu setiap ekor per hari yang menggunakan tiga macam konsentrat komersial dapat dilihat pada Tabel 4.

\section{Konsumsi asam amino arginine}

Berdasarkan hasil analisis sidik ragam untuk konsumsi arginine ayam petelur dalam peneltian ini menunjukkan perbedaan sangat nyata $(\mathrm{P}<0,01)$.
Konsumsi Arginine untuk ransum A (RA) yaitu 1104,12 mg/ekor/hari dan ransum B (RB) yaitu $1080,85 \mathrm{mg} /$ ekor/hari berdasarkan uji statistik adalah berbeda tidak nyata $(\mathrm{P}>0,05)$ tetapi konsumsi arginine untuk ransum $\mathrm{C}$ (RC) sebesar $1255,17 \mathrm{mg} / \mathrm{ekor} / \mathrm{hari}$ adalah sangat nyata lebih tinggi $(\mathrm{P}<0,01)$ dibanding konsumsi arginine dalam RA dan RB. Konsumsi arginine dalam RA, RB dan RC pada penelitian ini telah melebihi kebutuhan arginine untuk ayam petelur sebanyak 825 mg/ekor/hari (Rasyaf, 2003; Amrullah, 2004) dan sebanyak $1080 \mathrm{mg} /$ ekor/hari (Nesheim et al., 1979; Banerjee, 1982; Oliveira et al., 2014).

\section{Konsumsi asam amino lysine}

Berdasarkan hasil analisis sidik ragam untuk konsumsi lysine ayam petelur dalam penelitian ini menunjukkan perbedaan sangat nyata $(\mathrm{P}<0,01)$. Konsumsi lysine oleh ayam petelur untuk RA sebesar 759,95 mg/ekor/hari, untuk RB sebesar 743,37 mg/ekor/hari dengan uji statistik adalah berbeda tidak nyata $(\mathrm{P}>0,05)$, tetapi konsumsi lysine untuk RC sebesar 866,37 mg/ekor/hari adalah sangat nyata lebih tinggi $(\mathrm{P}<0,01)$ dibanding konsumsi lysine untuk RA dan RB. Kebutuhan lysine untuk ayam petelur adalah 725 mg/ekor/hari (Saha et al., 1999; Amrullah, 2004) dan 900 mg/ekor/hari untuk ayam petelur White Leghorn (Jacob et al., 2002; Skrivan et al., 2010). Konsumsi lysine dalam penelitian ini masih berada di atas kebutuhan ayam petelur yang dilaporkan Amrullah (2004), tetapi konsumsi lysine mendekati kebutuhan lysine untuk ayam petelur yang dilaporkan Jacob et al., (2002) yaitu konsumsi lysine dalam ransum $\mathrm{C}(\mathrm{RC})$.

\section{Konsumsi asam amino histidine}

Hasil analisis sidik ragam untuk konsumsi histidine ayam petelur dalam peneltian ini menunjukkan perbedaan sangat nyata $(\mathrm{P}<0,01)$. Konsumsi histidine 
Tabel 4. Rataan Konsumsi Asam-asam Amino Oleh Ayam Peterlur Umur 78 - 86 Minggu (mg/ekor/hari)

\begin{tabular}{|c|c|c|c|c|c|c|}
\hline \multirow{2}{*}{ Konsumsi } & \multirow{2}{*}{$\mathrm{n}$} & \multicolumn{3}{|c|}{ Ransum } & \multirow{2}{*}{$\begin{array}{c}\text { Level } \\
\text { Signifikan }\end{array}$} & \multirow{2}{*}{$\begin{array}{l}\text { Kebutuhan } \\
\text { Standar } \\
\text { asam-asam } \\
\text { Amino }^{+}\end{array}$} \\
\hline & & RA & $\mathrm{RB}$ & $\mathrm{RC}$ & & \\
\hline \multicolumn{7}{|l|}{ Asam-asam Amino } \\
\hline Arginine (mg) & 8 & $1104,12^{\mathrm{a}}$ & $1080,85^{\mathrm{a}}$ & $1255,17^{b}$ & $* *$ & 850 \\
\hline Lysine (mg) & 8 & $759,95^{\mathrm{a}}$ & $743,37^{\mathrm{a}}$ & $866,37^{\mathrm{b}}$ & $* *$ & 720 \\
\hline Histidine (mg) & 8 & $429,60^{\mathrm{a}}$ & $426,14^{\mathrm{a}}$ & $532,96^{\mathrm{b}}$ & $* *$ & 540 \\
\hline Leucine (mg) & 8 & $1528,64^{\mathrm{a}}$ & $1625,51^{\mathrm{a}}$ & $1909,15^{b}$ & $* *$ & 1280 \\
\hline Isoleucine (mg) & 8 & $728,67^{\mathrm{a}}$ & $726,44^{\mathrm{a}}$ & $852,73^{\mathrm{b}}$ & $* *$ & 850 \\
\hline Valine (mg) & 8 & $782,83^{\mathrm{a}}$ & $870,47^{\mathrm{b}}$ & $1034,03^{c}$ & $* *$ & 730 \\
\hline Methionine (mg) & 8 & $360,08^{a}$ & $397,42^{b}$ & $336,46^{\mathrm{a}}$ & $* *$ & 340 \\
\hline Threonine (mg) & 8 & $546,63^{\mathrm{a}}$ & $546,26^{\mathrm{a}}$ & $737,63^{b}$ & $* *$ & 630 \\
\hline Glycine & 8 & 1003,21 & 979,72 & 1013,11 & ns & $900^{++}$ \\
\hline $\begin{array}{l}\text { Phenylalanine } \\
(\mathrm{mg})\end{array}$ & 8 & $802,39^{a}$ & $818,19^{a}$ & $1002,7^{\mathrm{b}}$ & $* *$ & 780 \\
\hline $\begin{array}{l}\text { a,b,c rataan dalan } \\
\mathrm{ns}=\text { Non signifik } \\
\mathrm{n}=\text { Jumlah ulan } \\
+\quad \text { Scott, }(1976 \\
++\quad \text { Benerjee }(1\end{array}$ & aris & $\begin{array}{l}\text { g sama beı } \\
\text { ahju (1985 }\end{array}$ & a sangat $n$ & $(\mathrm{P}<0,01)^{*}$ & & \\
\hline
\end{tabular}

oleh ayam petelur untuk RA sebesar 429,60 mg/ekor/hari, untuk RB sebesar 426,14 mg/ekor/hari berdasarkan uji statistik adalah berbeda tidak nyata $(\mathrm{P}>0,05)$, tetapi konsumsi histidine untuk RC sebesar $532,96 \mathrm{mg} / \mathrm{ekor} /$ hari adalah sangat nyata lebih tinggi $(\mathrm{P}<0,01)$ dibanding konsumsi histidine untuk RA dan RB. Standard kebutuhan histidine ternak ayam petelur adalah 342 mg/ekor/hari (Benerjee, 1982; Tahmasbi et al., 2012). Dengan demikian konsumsi histidine ayam petelur pada penelitian ini berada diatas kebutuhan histidine oleh ayam petelur.

\section{Konsumsi asam amino leucine}

Konsumsi leucine ayam petelur dalam penelitian ini melalui analisis sidik ragam menunjukkan perbedaan sangat nyata $(\mathrm{P}<0,01)$. Konsumsi leucine oleh ayam petelur untuk RA sebesar 1528,64 mg/ekor/hari, untuk RB sebesar 1625,51 mg/ekor/hari berdasarkan uji statistik adalah berbeda tidak nyata $(\mathrm{P}>0,05)$ tetapi konsumsi leucine untuk RC sebesar $1909,15 \mathrm{mg} / \mathrm{ekor} /$ hari adalah sangat nyata lebih tinggi $(\mathrm{P}<0,01)$ dibanding konsumsi leucine untuk RA dan RB. Kebutuhan asam amino leucine oleh ayam petelur adalah $1350 \mathrm{mg} / \mathrm{ekor} / \mathrm{hari}$ (Banerjee, 1982). Dengan demikian konsumsi leucine untuk ketiga ransum (RA, RB dan $\mathrm{RC}$ ) dalam penelitian ini berada diatas standard kebutuhan leucine untuk ayam petelur (Banerjee, 1982; Tahmasbi et al., 2012).

\section{Konsumsi asam amino isoleucine}

Konsumsi isoleucine ayam petelur dalam penelitian ini melalui analisis sidik ragam menunjukkan perbedaan sangat nyata $(\mathrm{P}<0,05)$. Konsumsi isoleucine oleh ayam petelur untuk RA sebesar 728,67 mg/ekor/hari, untuk RB sebesar 726,44 mg/ekor/hari berdasarkan uji statistik 
adalah berbeda tidak nyata $(\mathrm{P}>0,05)$, tetapi konsumsi isoleucine untuk $\mathrm{RC}$ sebesar $852,73 \mathrm{mg} / \mathrm{ekor} /$ hari adalah sangat nyata lebih tinggi $(\mathrm{P}<0,01)$ dibanding konsumsi isoleucine untuk RA dan RB. Konsumsi isoleucine yang dibutuhkan oleh ayam petelur adalah berkisar $900 \mathrm{mg} / \mathrm{ekor} / \mathrm{hari}$ (Banerjee, 1982) sehingga konsumsi isoleucine ayam petelur dalam ransum (RA, RB) pada penelitian ini berada agak di bawah level konsumsi isoleucine sedangkan konsumsi isoleucine yang mendekati kebutuhan konsumsi (Banerjee (1982; Tahmasbi et al., 2012.) adalah RC.

\section{Konsumsi asam amino valine}

Konsumsi valine ayam petelur dalam penelitian ini melalui analisis sidik ragam menunjukkan perbedaan sangat nyata $(\mathrm{P}<0,01)$. Selanjutnya uji statistik menunjukkan bahwa konsumsi valine dalam RA yaitu 782,83 mg/ekor/hari adalah sangat nyata lebih tinggi $(\mathrm{P}<0,01)$ dibanding konsumsi valine dalam RB yaitu $870,47 \mathrm{mg} / \mathrm{ekor} / \mathrm{hari}$ dan dalam RC yaitu 1034,02 mg/ekor/hari, demikian juga konsumsi valine dalam $\mathrm{RC}$ adalah sangat nyta lebih tinggi $(\mathrm{P}<0,01) \quad$ dibanding konsumsi valine dalam RB. Asam amino valine yang dibutuhkan ayam petelur adalah berkisar $900 \mathrm{mg}$ /ekor/hari (Banerjee, 1982), sehingga konsumsi valine dalam RC pada penelitian ini masih berada diatas kebutuhan standar.

\section{Konsumsi asam amino methionine}

Konsumsi Asam amino methionine oleh ayam petelur berdasarkan analisis sidik ragam pada ketiga ransum yang mengandung konsentrat komersil A (RA), konsentrat komersil B (RB) dan konsentrat komersil $\mathrm{C}(\mathrm{RC})$ adalah berbeda sangat nyata $(\mathrm{P}<0,01)$ dimana konsumsi methionine oleh ayam petelur untuk RA sebesar 360,08 mg/ekor/hari dan untuk RC sebesar 336,46 mg/ekor/hari berdasarkan uji statistik adalah berbeda tidak nyata $(\mathrm{P}>0,05)$, tetapi konsumsi methionine untuk RB senesar 397,42 mg/ekor/hari adalah sangat nyata lebih tinggi $(\mathrm{P}<0,01)$ dibanding konsumsi methionine untuk RA dan RC. Asam amino methionine yang dibutuhkan untuk ayam petelur (Starcross Brown) umur 30 minggu adalah 359 mg/ekor/hari (Saha et al., 1999; Willemsen et al., 2011), untuk ayam petelur (IsaBrown) umur 50 - 62 minggu adalah 350 mg/ekor/hari (Cheva-Isarakul et al., 2001) dan untuk ayam petelur White Leghorn 39 - 47 minggu adalah $300 \mathrm{mg} / \mathrm{ekor} / \mathrm{hari}$ (Jacob et al., 2000; Xue et al., 2017.).

Dengan demikian kebutuhan konsumsi methionine dalam penelitian ini oleh ayam petelur tipe dwiguna hanya pada ransum $A$ (RA) dan ransum $B(R B)$ yang berada di atas standar kebutuhan methionine (350 mg/ekor/hari), sedangkan konsumsi methionine untuk ransum $\mathrm{C}$ (RC) dalam penelitian ini hanya berada di atas standar kebutuhan methionine ayam petelur tipe White Leghorn (300 mg/ekor/hari).

\section{Konsumsi asam amino threonine}

Konsumsi threonine ayam petelur dalam penelitian ini melalui analisis sidik ragam menunjukkan perbedaan sangat nyata $(\mathrm{P}<0,01)$. Konsumsi threonine oleh ayam petelur untuk RA sebesar 548,63 mg/ekor/hari, untuk RB sebesar 546,26 mg/ekor/hari berdasarkan uji statistik adalah berbeda tidak nyata $(\mathrm{P}>0,05)$, tetapi konsumsi threonine untuk RC sebesar $737,63 \mathrm{mg} / \mathrm{ekor} / \mathrm{hari}$ adalah sangat nyata lebih tinggi $(\mathrm{P}<0,01)$ dibanding konsumsi threonine untuk RA dan RB. Sesuai dengan standard kebutuhan threonine oleh Banerjee (1982) adalah sekitar 630 $\mathrm{mg} / \mathrm{ekor} / \mathrm{hari}$ maka konsumsi threoninine hanya terpenuhi dalam ransum $\mathrm{C}(\mathrm{RC})$.

\section{Konsumsi asam amino glycine}

Untuk konsumsi Glycine oleh ayam petelur pada ransum A (RA), ransum $B$ (RB) dan ransum $\mathrm{C}(\mathrm{RC})$, setelah dilakukan analisis sidik ragam menunjukkan perbedaan tidak nyata $(\mathrm{P}>0,05)$ dari ketiga jenis ransum tersebut, yaitu masing-masing 1003,21 mg/ekor/hari (RA) ; 979,72 mg/ekor/hari (RB) dan 1013,11 mg/ekor/hari (RC). Konsumsi Glycine 
dalam ransum $\mathrm{RA}, \mathrm{RB}$ dan $\mathrm{RC}$ pada penelitian ini adalah berada diatas standard kebutuhan glycine yang dilaporkan Banerjee (1982) yaitu 900 mg/ekor/hari.

\section{Konsumsi asam amino phenylalanine}

Konsumsi phenylalanine ayam petelur dalam penelitian ini melalui analisis sidik ragam menunjukkan perbedaan sangat nyata $(\mathrm{P}<0,01)$. Konsumsi phenylalanine oleh ayam petelur untuk RA sebesar 802,39 mg/ekor/hari, untuk RB sebesar 818,19 mg/ekor/hari berdasarkan uji statistik adalah berbeda tidak nyata $(\mathrm{P}>0,05)$, tetapi konsumsi phenylalanine untuk RC sebesar $1002,71 \mathrm{mg} / \mathrm{ekor} / \mathrm{hari}$ adalah sangat nyata lebih tinggi $(\mathrm{P}<0,01)$ dibanding konsumsi phenylalanine untuk RA dan RB. Konsumsi phenylalanine oleh ayam petelur dalam ransum RA, RB dan RC pada penelitian ini berada agak dibawah level standar konsumsi phenylalanine yang dilaporkan oleh Banerjee (1982) yaitu 1152 $\mathrm{mg} / \mathrm{ekor} / \mathrm{hari}$.

Secara umum penggunaan asamasam amino esensial oleh ternak adalah digunakan melalui fungsi hati, untuk mengurai dan mengaturnya dalam konsentrasi darah melalui keseimbangan rantai-rantai asam-asam amino lain termasuk non esensial dan keseimbangan ini diatur peran dan konsentrasinya oleh mekanisme aktifitas enzim (masih belum banyak diketahui) baik dalam darah dan otot maupun organ-organ produksi lainnya seperti telur pada ayam, susu untuk sapi dan lain-lain (Newsholme dan Leech, 1983).

\section{KESIMPULAN}

Hasil penelitian menunjukkan bahwa sebagian besar (80 \%) jumlah asam-asam amino esensial (Arginine, Lysine, Histidine, Leucine, Isoleucine, Valine, Threonine dan Phenylalanine) lebih tinggi pada RC dibanding RB dan RA, itu berarti komposisi asam-asam amino baik itu kualitas dan kuantitas dalam konsentrat komersil C (RC) adalah cukup dan lebih seimbang dibanding konsentrat komersil A (RA) dan konsentrat komersil B (RB).

\section{DAFTAR PUSTAKA}

Amrullah, I.K. 2004. Nutrisi Ayam Petelur. Lembaga SAtu Gunungbudi KPP IPB Bogor.

Banerjee, G.C. 1982. A Textbook of Animal Husbandry. Fifth Edition. Oxford \& IBH Publishing Co. New Delhi.

Bunglavan, S.J., A.K. Garg, R.S. Dass dan S. Shrivastava. 2014. Effect of supplementation of different levels of selenium as nanoparticles/sodium selenite on blood biochemical profile and humoral immunity in male Wistar rats. Veterinary World, 7(12): 1075-1081.

Cai, S.J., C.X. Wu, L.M. Gong, T. Song, H. Wu dan L.Y. Zhang. 2012. Effects of nano-selenium on performance, meat quality, immune function, oxidation resistance, and tissueselenium content in broilers. Poultry Science 91: 2532-2539.

Cheva-Israkul, B., S. Tangtaweewipat dan P. Sangsrijun. 2001. The Effect of Mustard Meal in Laying Hen Diets. Asian-Austr. Journal of Animal Science 13(12): 1743 - 1749

Delezie, E., M. Rovers, A. Van der Aa, A. Ruttens, S. Wittocx dan L. Segers. 2014. Comparing responses to different selenium sources and dosages in laying hens. Poultry Science 93(12): 3083-3090.

Hardjosubroto, W. dan J.M. Astuti. 1993. Buku Pintar Peternakan. PT Gramedia Widiasarana Indonesia Jakarta.

Hegazy, A. M., dan I.H. Badawy. 2010. Comparative effect of organic and inorganic forms of selenium on hypercholesterolemic rats. The Medical Journal of Cairo University 78(2): 393-398. 
Jacob, J.P., S. Ibrahim, R. Blair, H. Nankung dan I.K. Paik. 2000. Using enzyme supplemente, reduced protein diets to decrease Nitrogen and Phosphorus excretion of White Leghorn hens. Asian-Austr. Journal of Animal Science 13(12): 1743 1749.

Jing, C.L., X.F. Dong, Z.M. Wang, S. Liu dan J.M. Tong. 2015. Comparative study of DL-[Se] Met vs SS and seleno-yeast on antioxidant activity and selenium status in laying hens. Poultry Science 94(5):965-975.

Kazemi, F.M., H. Kermanshahi, M. Rezaei dan A. Golian. 2013. Effect of different levels of fennel extractand vitamin D3 on performance, hatchability andimmunity in post molted broiler breeders. Iranian Journal of Animal Science 3: 735745.

Marković, R., J. Ćirić, A. Drljačić, D. Šefer, I. Jovanović, D. Jovanović dan M. Starčević. 2018. The effects of dietary Selenium-yeast level on glutathione peroxidase activity, tissue Selenium content, growth performance, and carcass and meat quality of broilers. Poultry science 97(8), 2861-2870.

Mohapatra, P., R.K. Swain, S.K. Mishra, T. Behera, P. Swain, S.S. Mishra, N.C. Behura, S.C. Sabat, K. Sethy, K. Dhama dan P. Jayasankar. 2014. Effects of dietary nano selenium on tissue selenium deposition, antioxidant status and immune functions in layer chicks. International Journal of Pharmacology 10(3): 160-167.

Nassiri-Moghaddam, H., M. Kazemi-Fard, M.J. Agah, S.J. Hosseini dan M.T. Mirakzehi. 2012. Effect of different levels of methionine, protein and tallow on the productive performance and egg quality of laying hens in the late-phase production. Brazilian Journal of Poultry Science, 14(2):149-158.
Nesheim, M.C., R.E. Autis dan L.E. Card. 1979. Poultry Production. Lea and Febiger Philadelphia.

Newsholme, E.A. dan A.R. Leech. 1983. Biochemistry For The Medical Science. Jhon Wiley and Sons Ltd. New York

Oliveira, T.F.B., D.F.R. Rivera, F.R. Mesquita, H. Braga, E.M. Ramos dan A.G. Bertechini. 2014. Effect of different sources and levels of selenium on performance meat quality and tissue characteristics of broiler. The Journal of Applied Poultry Research, 23(1): 15-22.

Rasyaf, 2003. Penyajian Makanan Ayam Petelur. Kanisius Yogyakarta.

Saha, P.K., S.D. Chowdhury, S.C. Das dan S.K. Saha. 1999. Replacement value og two Bangladesh varieties of yellow corn for wheat in the diet of laying chicken. Asian-Austr. Journal og Animal Science 12(5): 776 - 782.

Steel, R.G.D. dan J.H. Torrie. 1993. Prinsip Dan Prosedur Statistik (Suatu Pendekatan Biometrik). Di terjemahkan oleh Bambang. Edisi Kedua. PT Gramedia Pustaka Utama Jakarta.

Skrivan, M., I. Bubancova, M. Marounek dan G. Dlouha. 2010. Selenium and alpha-tocopherol content in eggs produced by hens that were fed diets supplemented with selenomethionine, SS and vitamin E. Czech. Journal of Animal Science 55(9): 388-397.

Suprijatna, E., U. Atmomarsono dan R. Kartasudjana. 2005. Ilmu Dasar Ternak Unggas. Penebar Swadaya Jakarta.

Tahmasbi, A.M., M.T. Mirakzehi, S.J. Hosseini, M.J. Agah dan M. KazemiFard. 2012. The effects of phytase and root hydroalcoholic extract of Withania somnifera on productive performance and bone mineralization of laying hens in the late phase of production. British Poultry Science 53(2): 204-214. 
Wahju, J. 1985. Ilmu Nutrisi Unggas. Gadjah Mada University Press Yogyakarta.

Willemsen, H., Q. Swennen dan N. Everaert. 2011. Effects of dietary supplementation of methionine and its hydroxy analog DL-2-hydroxy-4methylthiobutanoic acid on growth performance, plasma hormone levels, and the redox status of broiler chickens exposed to high temperatures. Poultry Science 90(10): 2311-2320.

Xue, X., Y. Wang, W. Liu, T. Ju dan X. Zhan. 2017. Effects of different methionine sources on production and reproduction performance, egg quality and serum biochemical indices of broiler breeders. AsianAustralian Journal of Animal Science 30(6): 828-833. 